\title{
Effect of Lung Hypoplasia on Birth-Related Changes in the Pulmonary Circulation in Sheep
}

\author{
KEIJI SUZUKI, STUART B. HOOPER, MEGAN L. COCK, AND RICHARD HARDING \\ Department of Physiology, Monash University, Clayton, Victoria 3800, Australia
}

\begin{tabular}{|c|c|}
\hline \multicolumn{2}{|c|}{ ABSTRACT } \\
\hline $\begin{array}{l}\text { Lung hypoplasia (LH) is a serious cause of neonatal compro- } \\
\text { mise, but little is known of its functional effects on the pulmo- } \\
\text { nary circulation. Our aim was to characterize birth-related } \\
\text { changes in the pulmonary circulation of newborn lambs with LH } \\
\text { and to compare them with alterations in respiratory function. LH } \\
\text { was induced in six ovine fetuses by the creation of a tracheo- } \\
\text { amniotic shunt as well as amniotic fluid drainage starting at } 105.6 \\
\pm 1.5 \text { (mean } \pm \text { SEM) days of gestation (term } ~ 147 \mathrm{~d} \text { ). At } 139.9 \\
\pm 0.3 \mathrm{~d} \text {, fetuses were exteriorized under anesthesia to implant } \\
\text { vascular catheters and an ultrasonic flow probe around the left } \\
\text { pulmonary artery. The lambs then were delivered and ventilated } \\
\text { for } 2 \text { h, during which systemic and pulmonary artery pressures, } \\
\text { left pulmonary blood flow, and measures of respiratory function } \\
\text { were recorded. At autopsy, lungs were weighed and volume was } \\
\text { measured at } 20 \text { cm } \mathrm{H}_{2} \mathrm{O} \text {. In LH lambs, lung weight was } 25 \% \\
\text { lower and respiratory system compliance was } 30 \% \text { lower than in } \\
\text { controls. Mean pulmonary blood flow in LH lambs was } 42 \% \\
\text { lower and pulmonary vascular resistance was } 138 \% \text { higher than } \\
\text { in controls. Morphometry showed that volume density of pulmo- } \\
\text { nary arteries in LH was } 30 \% \text { lower than in controls. We conclude } \\
\text { that, in this LH model, changes in ventilatory indices were } \\
\text { proportional to the change in lung size, whereas changes in the } \\
\text { pulmonary circulation were greater than the change in lung size } \\
\text { and were associated with reduced density of pulmonary arteries. }\end{array}$ & 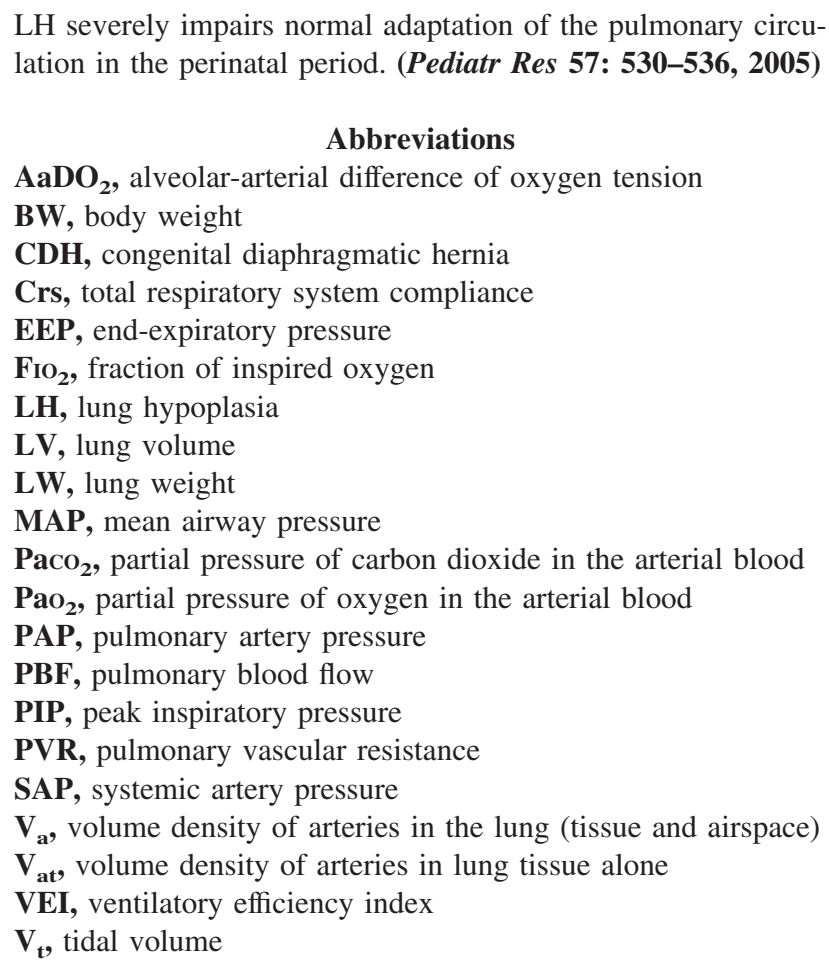 \\
\hline
\end{tabular}

Fetal lung hypoplasia (LH) results from impaired lung tissue growth during fetal development and can result in severe respiratory insufficiency in the neonate. $\mathrm{LH}$ is present in approximately one in 1000 human live births $(1,2)$, and, despite recent advances in the treatment of newborn infants with respiratory insufficiency, it remains one of the major causes of neonatal mortality and morbidity (3-5). The incidence of LH in neonatal autopsies is reportedly increasing because death rates as a result of other neonatal diseases are decreasing (6).

Received March 31, 2004; accepted September 2, 2004.

Correspondence: Keiji Suzuki M.D., Department of Physiology, Monash University, Clayton, VIC 3800, Australia; e-mail: dks@med.monash.edu.au.

This study was supported by the National Health and Medical Research Council of Australia.

DOI: 10.1203/01.PDR.0000155753.67450.01
LH is associated with many predisposing conditions (7), including chronic oligohydramnios, as a result of fetal anuria or amniotic fluid leakage (8-10), intrathoracic masses, as in congenital diaphragmatic hernia $(\mathrm{CDH})$, and decreased fetal breathing movements $(5,11)$. The impaired growth and structural development of the lung associated with LH has been reported in previous morphometric studies in human infants and experimental animal models. For example, radial alveolar counts are reduced in preterm infants with LH after premature rupture of membranes (10). Similarly, studies in animal models of LH have found reduced size and number of alveoli and alveolar ducts and thickened alveolar walls (12-14). Other studies have reported on the relationship between alterations in lung structure associated with LH and physiologic alterations in ventilatory function. In fetal rabbits with $\mathrm{LH}$, morphometric alterations in the lungs were associated with decreased dy- 
namic compliance of the air-filled lungs (12). Similarly, in infants who have $\mathrm{CDH}$, reductions in alveolar number and lung volume (LV) were correlated with higher partial pressure of carbon dioxide in the arterial blood $\left(\mathrm{PaCO}_{2}\right)$ and the need for ventilatory support (15).

It is apparent that LH is associated not only with reduced growth and altered structural development of the airways and respiratory units but also with impaired growth and development of the pulmonary vasculature. In an infant with LH associated with $\mathrm{CDH}$, reductions in the size and number of pulmonary arteries, airways, and alveoli were observed, and these reductions were closely related to the reduction in lung size (16). Other studies have reported the extension of muscularization further down the arterial tree and increased medial thickness of pulmonary arteries in human infants with LH $(17,18)$ as well as in animal models of $\mathrm{LH}$ induced by $\mathrm{CDH}$ (19). Decreased numbers and surface area of pulmonary capillaries have also been reported in animal models of $\mathrm{CDH}$ $(20,21)$. However, little is known about the physiologic aspects of perinatal adaptation of the pulmonary circulation in hypoplastic fetal lungs. Hence, our objectives were to characterize changes in pulmonary hemodynamics in newborn lambs with $\mathrm{LH}$ and to compare them with alterations in lung mechanics and ventilation. We induced LH by prolonged drainage of fetal lung liquid and amniotic fluid and ventilated the animals after birth as they were not expected to survive without respiratory support.

\section{METHODS}

Experiment protocol. The study was approved by the Animal Welfare Committee of Monash University. Twelve pregnant ewes and their fetuses (Merino $\times$ Border-Leicester) were anesthetized and underwent aseptic surgery at $105.6 \pm 1.5 \mathrm{~d}$ (mean \pm SEM) of gestation (term $\sim 147 \mathrm{~d}$ ). These animals were divided into two equal groups ( $n=6$ for each): an LH group and a control group. We implanted a fetal tracheal catheter (internal diameter $3.5 \mathrm{~mm}$, length $80 \mathrm{~mm}$, side holes at each end) and two amniotic fluid drainage catheters (internal diameter $3.5 \mathrm{~mm}$, length $250 \mathrm{~mm}$, side holes at each end) for the induction of LH. The fetal tracheal catheter acted as a tracheo-amniotic shunt and allowed fetal lung fluid to drain into the amniotic cavity. In addition, amniotic fluid was drained via the two amniotic catheters either into the maternal peritoneal cavity $(n=4)$ or into a sterile bag that was external to the ewe $(n=2)$. In the LH fetuses, amniotic and fetal lung fluids were drained passively from the time of surgery until delivery at $\sim 140 \mathrm{~d}$ of gestation. Five of the control fetuses underwent the same surgical preparation as LH animals but had a short re-entrant catheter (internal diameter $3.5 \mathrm{~mm}$, length $140 \mathrm{~mm}$, side holes at each end) or indwelling tube (internal diameter $3.5 \mathrm{~mm}$, length 50 $\mathrm{mm}$ ) implanted into the trachea; one control fetus received no surgical treatment. In control animals, amniotic and fetal lung fluids were not drained.

At $139 \pm 0.3 \mathrm{~d}$ of gestation, the pregnant ewes were anesthetized with halothane (3\%). The fetal head and chest were exteriorized, and catheters were inserted into a carotid artery and jugular vein; the existing tracheal tube was removed and replaced by an endotracheal tube for ventilation after birth. The trachea was ligated around the endotracheal tube to avoid any air leakage during ventilation. After a left thoracotomy, an ultrasonic flow probe (5-6SB; Transonic Systems, Ithaca, NY) was placed around the left pulmonary artery and a nonocclusive catheter was inserted into the main pulmonary artery. The lambs then were delivered, weighed, and laid in the right lateral posture on a mattress under a radiant heater. Amniotic fluid was collected before and after delivery of the fetus, and the volume was measured. Once delivered, the lambs were ventilated and monitored for $2 \mathrm{~h}$ with a constant-flow, time-cycled, pressure-controlled ventilator (Babylog 8000 Plus; Draeger Medizintechnik, Luebeck, Germany). Blood flow in the left pulmonary artery was measured with an ultrasonic flowmeter (T108; Transonic Systems). During the experiment, the lambs were anesthetized, sufficient to eliminate spontaneous respiration, with an i.v. infusion of alphaxalone/alphadolone acetate (Saffan; Pitman Moore, NSW, Australia) in glucose/saline solution, and respiratory and circu- latory data were recorded continuously using a digital data acquisition system (Powerlab/8sp; ADInstruments, NSW, Australia). The recorded respiratory and circulatory variables were fraction of inspired oxygen $\left(\mathrm{FIO}_{2}\right)$, ventilating pressures, ventilating flow and volume, systemic artery pressure (SAP), pulmonary artery pressure (PAP), and left pulmonary blood flow (PBF). Ventilating pressure, flow, and volume signals were obtained from the analogue outputs of the ventilator and recorded in a computer via an AD converter for further analyses.

The initial ventilator settings were as follows: flow, $6 \mathrm{~L} / \mathrm{min} ; \mathrm{FIO}_{2}, 1.0$; ventilation rate, 60 breaths/min; inspiration time, $0.5 \mathrm{~s}$; peak inspiratory pressure (PIP), $25 \mathrm{~cm} \mathrm{H}_{2} \mathrm{O}$; end-expiratory pressure (EEP), $5 \mathrm{~cm} \mathrm{H}_{2} \mathrm{O}$. These settings were adjusted every $5-15$ min according to the arterial blood gas tensions and tidal volume $\left(\mathrm{V}_{\mathrm{t}}\right)$, aiming for target values of $\mathrm{PaCO}_{2} 35-45 \mathrm{~mm}$ $\mathrm{Hg}$; $\mathrm{PaO}_{2} 60-100 \mathrm{~mm} \mathrm{Hg}$; and $\mathrm{V}_{\mathrm{t}} 5-10 \mathrm{~mL} / \mathrm{kg}$ body weight. The PIP was adjusted depending on $\mathrm{V}_{t}$, and then ventilation rate was adjusted depending on $\mathrm{PaCO}_{2}$ values. The $\mathrm{FIO}_{2}$ was adjusted depending on the $\mathrm{PaO}_{2}$. The EEP was kept at $5 \mathrm{~cm} \mathrm{H}_{2} \mathrm{O}$ at least for the first hour; after $1 \mathrm{~h}$, if the $\mathrm{PaO}_{2}$ exceeded $100 \mathrm{~mm}$ $\mathrm{Hg}$ on $\mathrm{FIO}_{2}$ of 0.4, then the EEP was decreased in 1-cm $\mathrm{H}_{2} \mathrm{O}$ increments.

After $2 \mathrm{~h}$ of ventilation, lambs were killed painlessly by a lethal dose of sodium pentobarbitone ( $1.5 \mathrm{~g}$, i.v.). The lungs and heart were removed and weighed. After the left bronchus was ligated, the left lung was removed and portions were frozen in liquid nitrogen and then stored at $-70^{\circ} \mathrm{C}$ for biochemical analysis; other portions were removed for dry weight analysis. The right lung was fixed via the trachea at $20 \mathrm{~cm} \mathrm{H}_{2} \mathrm{O}$ with $4 \%$ paraformaldehyde. After $3-5 \mathrm{~d}$ of fixation (for future histologic analysis), the right LV was determined using the Cavalieri method (22). Pulmonary DNA and soluble protein concentrations in lung tissue were determined using established fluorometric DNA and colorimetric protein assays (23).

Data analysis. Data relating to blood gas tensions, ventilatory pressure, flow and volume, left PBF, and pulmonary and systemic artery pressures were analyzed at 15, 30, 60, 90, and 120 min after birth. At each time point, values from five consecutive cycles of ventilation or heart beat were sampled and averaged for further analysis.

We calculated the following four derived variables:

1. Alveolar-arterial difference of oxygen tension $\left(\mathrm{AaDO}_{2} ; \mathrm{mm} \mathrm{Hg}\right)$, an index of oxygenation: $\mathrm{FIO}_{2} \times(760-52)(\mathrm{mm} \mathrm{Hg})-\mathrm{PaCO}_{2}(\mathrm{mmHg}) / 0.8-$ $\mathrm{PaO}_{2}(\mathrm{mmHg})$, where $760 \mathrm{~mm} \mathrm{Hg}$ is mean atmospheric pressure at our laboratory, $52 \mathrm{~mm} \mathrm{Hg}$ is saturated water vapor pressure at $39^{\circ} \mathrm{C}$ and 0.8 is an assumed RQ (respiratory quotient).

2. Ventilatory efficiency index (VEI) (24), an index of $\mathrm{CO}_{2}$ elimination efficiency: 3800/ventilation rate $(/ \mathrm{min}) /(\mathrm{PIP}-\mathrm{EEP})\left(\mathrm{cm} \mathrm{H}_{2} \mathrm{O}\right) / \mathrm{PaCO}_{2}$.

3. Total respiratory system compliance $\left(\mathrm{Crs} ; \mathrm{mL} / \mathrm{cm} \mathrm{H}_{2} \mathrm{O}\right)$ : volume difference between end-inspiration and end-expiration/pressure difference between end-inspiration and end-expiration (at points of no flow)

4. Pulmonary vascular resistance (PVR; $\left.\mathrm{mm} \mathrm{Hg} \cdot \mathrm{mL}^{-1} \cdot \min \right)$ : (mean PAP $-5)(\mathrm{mmHg}) / \mathrm{meanPBF}(\mathrm{mL} / \mathrm{min})$. Left atrial pressure was assumed to be $5 \mathrm{~mm} \mathrm{Hg}$.

Morphometry. From the right lung of each animal, nine paraffin-embedded sections of $4-\mu \mathrm{m}$ thickness were stained with Masson's trichrome stain. Pulmonary arteries were distinguished from pulmonary veins on the basis of structure and position (25). From each section, three different fields were randomly selected and examined at $\times 100$ magnification, with a total of 27 fields per animal analyzed, using ImagePro Plus Version 4.5 for Windows Image Analysis (Media Cybernetics, Silver Spring, MD). The external elastic lamina of all arteries with diameter $>25 \mu \mathrm{m}$ was traced and the areas within the lamina were summated. The area of tissue (nonairspace areas) was also measured using an automated counting system in the same computer program that recognizes and summates dark areas. Volume density of arteries in the lung $\left(\mathrm{V}_{\mathrm{a}}\right)$ is defined as the total area occupied by arteries relative to the total field area. Volume density of arteries in lung tissue $\left(\mathrm{V}_{\mathrm{at}}\right)$ is defined as the total area occupied by arteries relative to the area occupied by tissue (airway walls, blood and lymph vessels, connective tissue, capillaries, and alveolar septae).

The results are presented as mean \pm SEM. Differences among the animal characteristics, autopsy data, and lung composition data were analyzed using an unpaired $t$ test. Differences in respiratory and circulatory variables over time and between groups were analyzed using a two-way ANOVA for repeated measures. Significant differences then were identified with a least significant difference test. The level of significance for all statistical analyses was $p<$ 0.05 .

\section{RESULTS}

The gestational ages at the time of treatment onset, namely tracheal tube and amniotic catheter implantation, were not 
different between $\mathrm{LH}$ and control animals (105.5 \pm 2.5 versus $105.8 \pm 1.4 \mathrm{~d})$. Similarly, the gestational ages at delivery $(140.0 \pm 0.5$ versus $139.8 \pm 0.2 \mathrm{~d})$ and birth weights $(3.33 \pm$ 0.18 versus $3.66 \pm 0.29 \mathrm{~kg}$ ) of the $\mathrm{LH}$ and control groups were not different. Amniotic fluid volume was decreased by $58 \%$ in LH animals compared with controls (Table 1). No overt fetal anomalies were observed.

Lung growth. The wet and dry lung/body weight ratios were reduced, respectively, by $25 \%(p<0.05)$ and $28 \%(p<0.01)$ in LH lambs compared with controls (Table 1). Similarly, total lung DNA content ( $\mathrm{mg} / \mathrm{kg}$ body weight) was reduced by $22 \%$ $(p<0.05)$ in LH lambs compared with controls (Table 1). Total lung protein content ( $\mathrm{g} / \mathrm{kg}$ body weight) tended to be lower in LH than in control lambs; however, the difference was not significant $(p=0.096)$. The concentration of both DNA $(\mathrm{mg} / \mathrm{g})$ and protein $(\mathrm{mg} / \mathrm{g})$ of lung tissue was not different between the groups. $\mathrm{LV}$ at $20 \mathrm{~cm} \mathrm{H}_{2} \mathrm{O}$ was $39 \%$ lower in $\mathrm{LH}$ lambs compared with controls $(p<0.01)$.

Oxygenation and ventilation. Arterial pH ( $\mathrm{LH} 7.396 \pm$ 0.086 versus control $7.437 \pm 0.042$ at $2 \mathrm{~h}), \mathrm{Paco}_{2}(\mathrm{LH} 36.6 \pm$ 5.3 versus control $34.8 \pm 2.3 \mathrm{~mm} \mathrm{Hg}$ at $2 \mathrm{~h}$ ), and $\mathrm{PaO}_{2}(\mathrm{LH} 94$ \pm 23 versus control $75 \pm 15 \mathrm{~mm} \mathrm{Hg}$ at $2 \mathrm{~h}$ ) were not significantly different between the two groups of lambs over the 2-h study period. The hematocrit of the lambs at $2 \mathrm{~h}$ after birth was not different between the groups $(39.3 \pm 2.6$ versus $38.6 \pm 1.3 \%$ ). The $\mathrm{FIO}_{2}$ required to maintain the target $\mathrm{PaO}_{2}$ was reduced at a greater rate in control lambs than in $\mathrm{LH}$ lambs. The $\mathrm{FIO}_{2}$ was significantly higher in $\mathrm{LH}$ lambs than in controls at 15 and 30 min but was not different at 60, 90, and 120 min (Fig. 1A). After delivery, PIP, ventilation rate and mean airway pressure (MAP) progressively decreased in both groups; however, they decreased more slowly in LH lambs than in controls. The PIP was not different between groups at 15 min but was significantly higher in LH lambs than in controls at $30,60,90$, and $120 \mathrm{~min}(21.0 \pm 1.5$ versus $16.0 \pm$ $3.6 \mathrm{~cm} \mathrm{H}_{2} \mathrm{O} ; p<0.01$ at $2 \mathrm{~h}$ ). The PEEP remained at $5 \mathrm{~cm} \mathrm{H}_{2} \mathrm{O}$ in all LH lambs, but it was able to be reduced in five control lambs at $1 \mathrm{~h}$ after birth. It was significantly higher in $\mathrm{LH}$ than in control lambs at 90 and $120 \mathrm{~min}(5.0 \pm 0.0$ versus $2.8 \pm 1.6$ $\mathrm{cm} \mathrm{H}_{2} \mathrm{O} ; p<0.01$ at $2 \mathrm{~h}$ ). The ventilation rate progressively declined in both groups and at $2 \mathrm{~h}$ tended to be higher in $\mathrm{LH}$ than in control lambs $(35.0 \pm 5.5$ versus $31.7 \pm 2.6 / \mathrm{min} ; p=$ $0.207)$. The MAP was not different between groups at $15 \mathrm{~min}$ but was significantly higher in LH lambs than in controls at 30, 60, 90, and 120 min (Fig. 1B). The $\mathrm{AaDO}_{2}$ decreased with time

Table 1. Amniotic fluid volume and data relating to lung size in the LH and control groups

\begin{tabular}{lcc}
\hline \multicolumn{1}{c}{ Variable } & LH & Control \\
\hline Amniotic fluid volume $(\mathrm{mL})$ & $183 \pm 69^{\mathrm{a}}$ & $433 \pm 44$ \\
Wet LW (g/kg BW) & $21.7 \pm 1.3^{\mathrm{a}}$ & $29.1 \pm 2.4$ \\
Dry LW (g/kg BW) & $2.67 \pm 0.10^{\mathrm{b}}$ & $3.72 \pm 0.19$ \\
Lung DNA (mg/kg BW) & $145.0 \pm 6.7^{\mathrm{a}}$ & $185.5 \pm 12.5$ \\
Lung protein $(\mathrm{g} / \mathrm{kg} \mathrm{BW})$ & $0.918 \pm 0.046$ & $1.384 \pm 0.249$ \\
LV (mL/kg BW) & $23.2 \pm 1.2^{\mathrm{b}}$ & $38.0 \pm 2.4$ \\
\hline
\end{tabular}

Wet LW, dry LW, lung DNA content, lung protein content, and LV (at 20 $\mathrm{cm}_{2} \mathrm{O}$ fixation pressure) are adjusted for $\mathrm{BW}$ in $\mathrm{kg}$. Values are mean \pm SEM. Significant differences between the LH and control groups: ${ }^{\mathrm{a}} p<0.05,{ }^{\mathrm{b}} p<$ 0.01 . in both groups of lambs; during the first hour after birth, it decreased more quickly in LH than in control lambs. After this time, however, the difference between groups did not reach statistical significance (Fig. $1 C$ ).

VEI significantly increased with time in both groups and was lower in LH than in control lambs. The difference between groups was significant at 90 and $120 \mathrm{~min}$; at $120 \mathrm{~min}$, VEI was $28 \%$ lower than in controls $(0.20 \pm 0.02$ versus $0.27 \pm 0.03$; $p<0.05$; Fig. 2A). Crs adjusted for body weight (Crs/BW) significantly increased in both groups and was lower in LH than in control lambs over the study period; the difference was significant at $15,60,90$, and $120 \mathrm{~min}$; at $120 \mathrm{~min}, \mathrm{Crs} / \mathrm{BW}$ was $30 \%$ lower in $\mathrm{LH}$ lambs than in controls $(0.40 \pm 0.03$ versus $0.57 \pm 0.04 \mathrm{~mL} \cdot \mathrm{cm} \mathrm{H}_{2} \mathrm{O}^{-1} \cdot \mathrm{kg}^{-1} ; p<0.05$; Fig. 2B). In contrast, neither Crs adjusted for lung weight (LW) nor Crs adjusted for LV was different between the groups at all time points.

Pulmonary circulation. Blood flow through the left pulmonary artery, adjusted for BW (meanPBF/BW), was significantly lower in LH than in control lambs at all time points (Fig. $3 A)$; at $120 \mathrm{~min}$, it was $42 \%$ lower $(p<0.01)$ in LH lambs $\left(49.4 \pm 5.9 \mathrm{~mL} \cdot \mathrm{min}^{-1} \cdot \mathrm{kg}^{-1}\right)$ than in controls $(85.4 \pm 9.0$ $\mathrm{mL} \cdot \min ^{-1} \cdot \mathrm{kg}^{-1}$ ). Maximum PBF adjusted for BW (max$\mathrm{PBF} / \mathrm{BW}$ ) was significantly lower in LH than in control lambs (Fig. 3B); at $120 \mathrm{~min}$, it was $33 \%$ lower $(p<0.05)$ in $\mathrm{LH}$ lambs $\left(148.1 \pm 13.9 \mathrm{~mL} \cdot \min ^{-1} \cdot \mathrm{kg}^{-1}\right)$ than in controls $\left(220.7 \pm 28.1 \mathrm{~mL} \cdot \mathrm{min}^{-1} \cdot \mathrm{kg}^{-1}\right)$. Minimum PBF adjusted for $\mathrm{BW}$ (minPBF/BW) was lower in LH than in control lambs over the study period (significant difference at 15, 60, and $120 \mathrm{~min}$ ). At $120 \mathrm{~min}$, $\mathrm{minPBF} / \mathrm{BW}$ was $-1.8 \pm 6.3 \mathrm{~mL} \cdot \mathrm{min}^{-1} \cdot \mathrm{kg}^{-1}$ in $\mathrm{LH}$ lambs and $23.0 \pm 4.2 \mathrm{~mL} \cdot \mathrm{min}^{-1} \cdot \mathrm{kg}^{-1}$ in controls (Fig. 3C). In two of the control lambs, minPBF/BW was negative (i.e. reverse flow) at $15 \mathrm{~min}$ but was positive in all control lambs at 90 and $120 \mathrm{~min}$. In contrast, all LH lambs showed negative $\operatorname{minPBF} / \mathrm{BW}$ at 15 and $30 \mathrm{~min}$, and in two of them, it remained negative at $120 \mathrm{~min}$. Figure 4 shows typical $\mathrm{PBF}$ waveforms in LH and control lambs at $120 \mathrm{~min}$; in control lambs, PBF remained positive throughout the cardiac cycle, and the decrease in flow immediately after systole was reduced compared with LH lambs. In contrast, in LH lambs, PBF rapidly decreased after systole and commonly decreased below zero, indicating retrograde flow in the pulmonary artery (a characteristic of the fetal state; Fig. 4). Mean PBF adjusted for LW tended to be lower in LH compared with control lambs, reaching significance only at $30 \mathrm{~min}$; at $2 \mathrm{~h}$, the values were not significantly different (LH $5.68 \pm 2.17$ versus control $7.65 \pm$ $\left.2.52 \mathrm{~mL} \cdot \min ^{-1} \cdot \mathrm{g}^{-1}\right)$.

Mean PAP was higher in LH than in control lambs over the study period (significant differences at 15, 60, and $120 \mathrm{~min}$ ) and was $34 \%$ higher at $120 \mathrm{~min}(41.3 \pm 2.4$ versus $30.8 \pm 0.8$ $\mathrm{mm} \mathrm{Hg} ; p<0.01$; Fig. 5A). The ratio of mean PAP to mean SAP (PAP/SAP) was significantly higher in LH than in control lambs at all time points and was $68 \%$ greater at $120 \mathrm{~min}(1.01$ \pm 0.07 versus $0.60 \pm 0.04 ; p<0.01$; Fig. $5 B$ ). At $120 \mathrm{~min}$, three LH lambs still showed PAP/SAP $>1$ (i.e. mean PAP was higher than mean SAP). In contrast, in all control lambs, PAP/SAP was $<1$ (i.e. mean PAP was lower than mean SAP) at all time points. PVR adjusted for body weight $(\mathrm{PVR} * \mathrm{BW})$ 

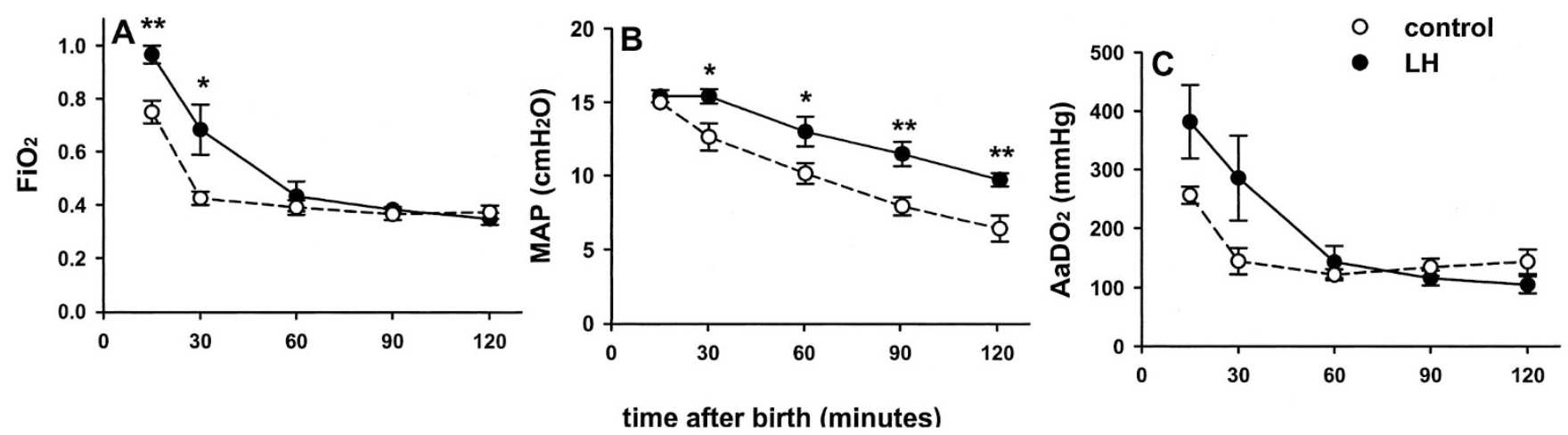

Figure 1. Changes over the 2-h study period in $\mathrm{FIO}_{2}(A), \mathrm{MAP}(B)$, and $\mathrm{AaDO}_{2}(C)$ in the $\mathrm{LH}(\bullet)$ and control $(\bigcirc)$ groups. Data are mean \pm SEM. Differences between LH and control groups: $* p<0.05, * * p<0.01$.

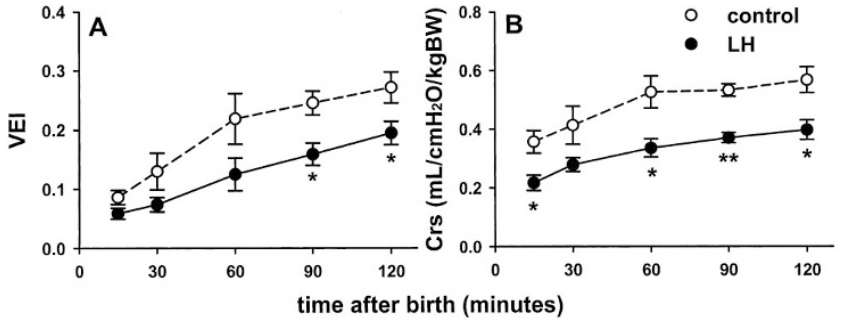

Figure 2. Changes over the 2-h study period in VEI $(A)$ and Crs $(B)$ adjusted for body weight $(\mathrm{Crs} / \mathrm{BW})$, in the LH $(\bullet)$ and control $(\bigcirc)$ groups. Data are mean \pm SEM. Differences between LH and control group: $* p<0.05$, ${ }^{* *} p<$ 0.01 .

was significantly higher in LH than in control lambs at all time points and was $138 \%$ higher at $120 \mathrm{~min}(0.76 \pm 0.06$ versus $0.32 \pm 0.04 \mathrm{~mm} \mathrm{Hg} \cdot \mathrm{mL}^{-1} \cdot \mathrm{min} \cdot \mathrm{kg} ; p<0.01$; Fig. 5C). PVR adjusted for LW (PVR*LW) was also higher in LH than in control lambs (significant difference at 15, 30, and $120 \mathrm{~min}$ ) and was $82 \%$ higher at $120 \mathrm{~min}(6.9 \pm 0.7$ versus $3.8 \pm 0.6$ $\left.\mathrm{mm} \mathrm{Hg} \cdot \mathrm{mL}^{-1} \cdot \min \cdot \mathrm{g} ; p<0.05\right)$. In LH lambs, both PVR*BW and PVR*LW decreased with time but did not reach the level measured in control lambs, which showed constant low values over the 2-h experiment.

Morphometry of pulmonary arteries. The $\mathrm{V}_{\mathrm{a}}$ tended to be lower in LH lambs than in controls $(2.70 \pm 0.35$ versus $3.82 \pm$ $0.37 \times 10^{-3} ; p=0.051$; Fig. $6 A$ ). The $\mathrm{V}_{\text {at }}$ was significantly lower in LH lambs than in controls $(10.5 \pm 0.9$ versus $15.1 \pm$ $1.1 \times 10^{-3} ; p<0.05$; Fig. $\left.6 B\right)$.

\section{DISCUSSION}

In this study, we induced moderate LH in fetal sheep by creating a tracheo-amniotic shunt and draining amniotic fluid for $\sim 35 \mathrm{~d}$. This treatment was expected to chronically reduce the level of fetal lung expansion and hence inhibit lung growth during the canalicular, saccular/alveolar phases of lung development. Immediately after birth, the LH was associated with a decreased $\mathrm{Crs}$ and increased ventilatory requirements. In addition, we found major differences between groups in PVR, PBF, and PAP, which are indicative of major alterations within the pulmonary circulation and are consistent with the decrease in the volume density of arteries in lung tissue.

Creation of lung hypoplasia. A number of animal models have been used to create fetal LH by mimicking human clinical situations that cause LH (26-29). We induced lung hypoplasia by the combined drainage of fetal lung liquid and amniotic fluid. A reduced volume of amniotic fluid (oligohydramnios) is known to be associated with LH by causing either direct or posture-related (increased "ventroflexion") compression of the lungs, although decreased fetal breathing movements may also contribute $(10,28,30-32)$. The fetal tracheo-amniotic shunt is likely to accentuate the reduction in lung expansion (and thus LH) associated with oligohydramnios by creating a lowresistance pathway for fetal lung liquid to leave the lungs $(30,33)$. Our method of prolonged drainage of amniotic and lung fluid was successful in inducing a moderate degree of fetal lung hypoplasia, as indicated by the $28 \%$ reduction in dry LW and $22 \%$ reduction in pulmonary DNA content in LH lambs compared with controls $(30,34)$. In most cases, amniotic fluid drainage was incomplete, perhaps as a result of trapped pockets of fluids or a small pressure gradient between the amniotic sac and maternal peritoneal cavity or the fluid collecting bag, which may have been responsible for the relatively modest degree of LH that we observed. Nevertheless, this degree of LH was sufficient to cause significant changes in respiratory function and PBF in ventilated neonatal lambs.

Oxygenation and ventilation. A number of previous studies have reported decreased oxygenation and ventilation in neonates with $\mathrm{LH}$. In our study, the $\mathrm{FIO}_{2}$ was reduced more quickly in control lambs than in LH lambs within the first hour after birth, although it was not different between the two groups after 60 min. The $\mathrm{AaDO}_{2}$ was higher in LH lambs than in controls within the first hour and was not different between the two groups after $60 \mathrm{~min}$. These results indicate that in this model, LH lambs had poorer oxygenation immediately after birth and improved less rapidly than controls, attaining a near-normal oxygenation level by $1 \mathrm{~h}$ after birth. This mild impairment of oxygenation could be a result of the moderate degree of LH created in this study.

In contrast to the similar oxygen requirements in both groups at $1 \mathrm{~h}$ after birth, the persistent difference in MAP and VEI between the two groups over the postnatal study period indicates that ventilatory efficiency was decreased in LH lambs and that these animals required more ventilatory support as indicated by higher ventilating pressure settings. It is interesting that $\mathrm{Crs} / \mathrm{BW}$ showed similar trends to those of VEI; that is, both $\mathrm{Crs} / \mathrm{BW}$ and VEI increased with time but were lower in 

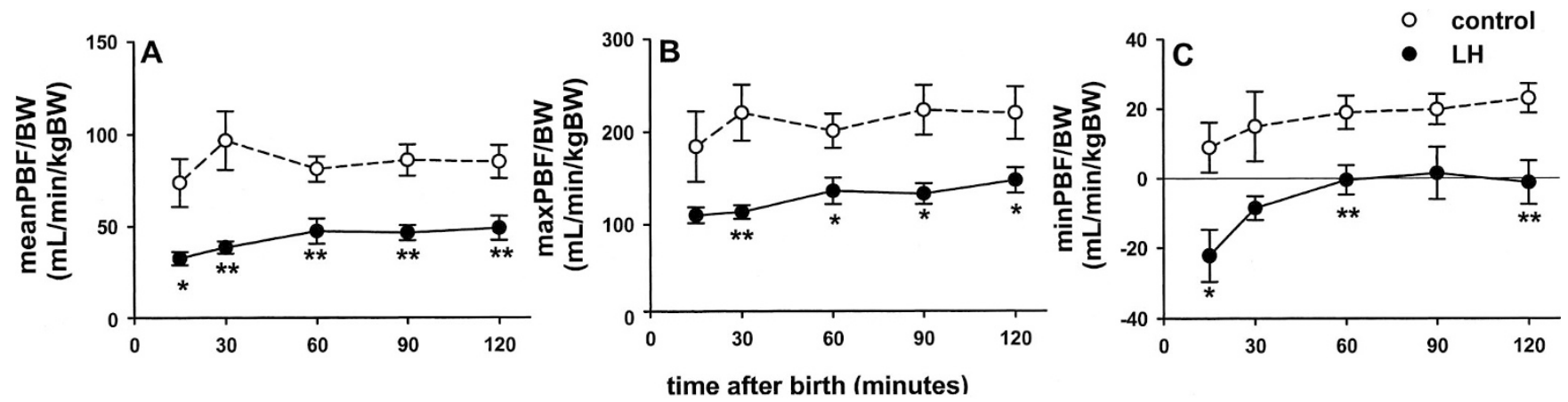

Figure 3. Changes over the 2-h study period in mean meanPBF/BW $(A), \operatorname{maxPBF} / \mathrm{BW}(B)$, and minPBF/BW $(C)$ in the LH $(\bullet)$ and control $(\bigcirc)$ groups. Data are mean \pm SEM. Differences between LH and control groups: ${ }^{*} p<0.05, * * p<0.01$.
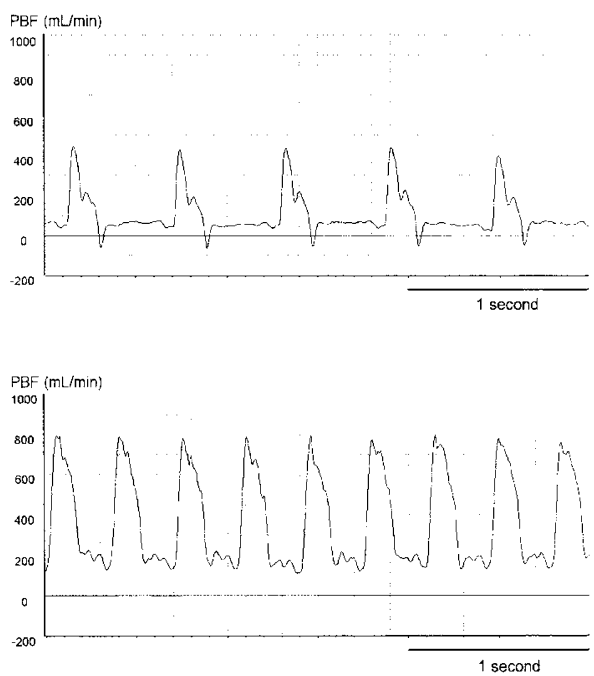

Figure 4. Records of left PBF waveforms at $2 \mathrm{~h}$ after birth from a lamb $(A)$ with $\mathrm{LH}$ and a control lamb $(B)$.

LH lambs over the whole experiment. At $120 \mathrm{~min}$, the reductions in VEI and Crs/BW were 28 and $30 \%$, respectively, which were similar to the reductions in wet and dry LWs $(25$ and $28 \%$, respectively). Hence, assuming that $\mathrm{CO}_{2}$ production and the physiologic dead space were not different between the groups, alveolar ventilation rate was also proportional to lung size. Crs adjusted for $\mathrm{LW}(\mathrm{Crs} / \mathrm{LW})$ and Crs adjusted for $\mathrm{LV}$ $(\mathrm{Crs} / \mathrm{LV})$ were not different between the groups. Alterations in the development of type I and II alveolar epithelial cells and in the production of surfactant in LH are controversial $(12,35)$. However, the above results suggest that the change in lung compliance was due to the change in lung size and not to any superimposed factors such as a deficiency in surfactant production or release.

Pulmonary circulation. A major finding was that PVR was much higher in LH lambs than in controls. Although PVR decreased in LH lambs with time, even at $2 \mathrm{~h}$ after birth, PVR adjusted for either BW or LW was still 138 and $82 \%$ higher, respectively, in LH lambs than in controls. Our findings indicate that the increase in PVR was more marked than what could be expected from the decrease in lung size, resulting in a severe impairment of the perinatal adaptation of the pulmonary vascular system in LH animals. The LH-induced increase in PVR would explain the observed decreases in meanPBF,
maxPBF, and minPBF. An increase in PVR would also explain the higher PAP in LH lambs compared with controls; indeed, in LH lambs, PAP remained around the same level as mean SAP throughout the study period.

A previous study has examined the effect of $\mathrm{LH}$ on $\mathrm{PBF}$ (using the microsphere method), PAP, and PVR in a fetal ovine model of CDH (36). In the LH fetuses, it was found that PBF was reduced and both PAP and PVR were increased. However, when adjusted for LW, PBF was not decreased (i.e. the decrease in PBF was proportional to the reduction in the lung mass) and PVR was increased only slightly; the increase in PVR was more than proportional to the reduction in the lung mass but was not significant (36). In our study, the increase in PVR was greater than what could be attributed to the decrease in lung size. Pulmonary vascular tone is known to be affected by oxygen tension and $\mathrm{pH}(37,38)$, but in this study, we found no difference in $\mathrm{FIO}_{2}, \mathrm{PaO}_{2}$, and $\mathrm{pH}$ between the two groups over the second half of the study period. Hence, $\mathrm{O}_{2}$ tension and $\mathrm{pH}$ around the distal pulmonary arteries would be expected to be at the same level in both groups.

To explain the higher PVR in LH lambs, relative to lung size, there are three major possibilities. First, the growth and development of the pulmonary vascular bed in LH lambs might be more severely impaired than that of airspace and overall lung tissue growth. This would lead to a reduced crosssectional area of the pulmonary vascular bed and hence an increase in its resistance. This explanation is compatible with our morphometric findings, which showed a $30 \%$ decrease in volume density of arteries relative to tissue volume $\left(\mathrm{V}_{\mathrm{at}}\right)$. Assuming that tissue volume is related to tissue weight, the significant reduction in $\mathrm{V}_{\mathrm{at}}$ would likely cause an increase in arterial resistance and hence an increase in PVR. In our model of $\mathrm{LH}$, lung liquid and amniotic fluid drainage occurred in the canalicular $(\sim 80-120$ d) and saccular/alveolar stages $(\sim 120-$ $140 \mathrm{~d}$ ) of lung development. Therefore, the development of pulmonary capillaries may have been affected by the treatment. Some previous studies of pulmonary capillary development in a CDH model revealed a decrease in the capillary surface area that was proportional to the reduction in alveolar surface area $(20,21)$. However, in this study, the analysis of pulmonary capillaries was not possible because we pressure-fixed the lung tissue via the airways without concomitant perfusion fixation 

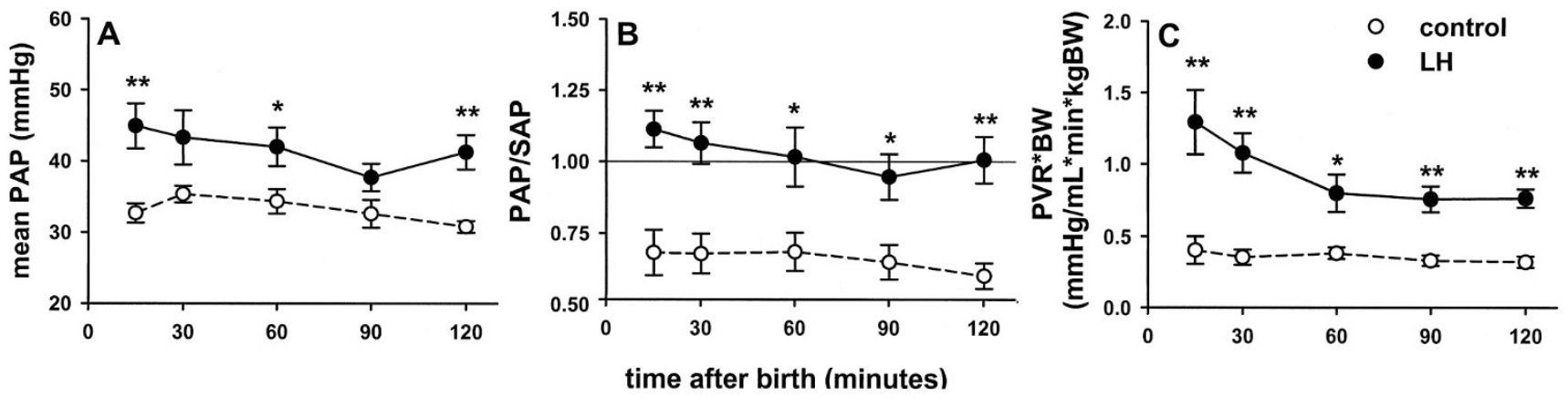

Figure 5. Changes over the 2-h study period in mean PAP $(A)$, mean PAP/SAP $(B)$, and PVR*BW $(C)$ in the LH $(\bullet)$ and control $(\bigcirc)$ groups. Data are mean \pm SEM. Differences between LH and control groups: $* p<0.05,{ }^{*} p<0.01$.
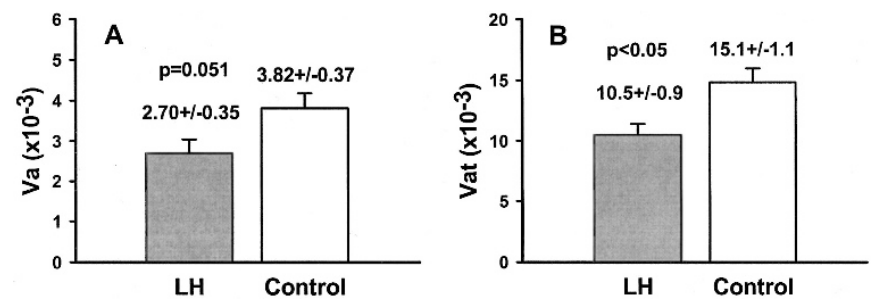

Figure 6. $\mathrm{V}_{\mathrm{a}}(A)$ and $\mathrm{V}_{\mathrm{at}}(B)$ in the $\mathrm{LH}($ 圆) and control $(\square)$ groups. Data are mean \pm SEM.

through pulmonary vessels, which caused a collapse of capillaries.

Second, as PVR is dependent on the capillary-alveolar transmural pressure, higher alveolar pressures resulting from higher MAP (39) may lead to compression of pulmonary capillaries (40) and hence increased PVR (41). Therefore, we cannot exclude the possibility that the higher MAP in our LH animals contributed to the increased PVR by increasing pulmonary capillary resistance. In fact, there was a significant correlation between MAP and PVR*LW in the LH group of lambs $(p<$ $\left.0.01, r^{2}=0.32\right)$ but not in the control group $\left(p=0.70, r^{2}=\right.$ 0.01 ). This may indicate that a more severe LH resulted in the need for higher MAP to maintain adequate ventilation, which in turn caused a higher PVR.

Third, it is possible that the higher PVR in lambs with LH resulted from increased vasoconstrictor tone in the peripheral pulmonary arteries. It is well established that neonatal persistent pulmonary hypertension associated with $\mathrm{LH}$ responds to vasodilator treatment $(5,42-44)$. Thus, the greater increase in PVR relative to the reduction in lung size in the present study could be the consequence of increased vasoconstrictor activity of the pulmonary arteries. Further studies examining the physiologic responses of the pulmonary vasculature to various vasodilating and vasoconstricting challenges would be required to elucidate this point.

In contrast to all control lambs, we found a persistence of diastolic retrograde flow in the left pulmonary artery in four LH lambs. We speculate that this is caused by a persistent elevation of PVR in association with continued right-to-left shunting through the patent ductus arteriosus. Our observation that the mean PAP relative to SAP stayed significantly high in LH lambs supports this speculation.

\section{CONCLUSIONS}

In our ovine model of moderate LH, changes in indices of lung ventilation were proportional to the changes in lung size. Changes in indices of pulmonary circulation were greater than the changes in lung size despite similar $\mathrm{FIO}_{2}$ and oxygenation and were associated with impaired growth of pulmonary arteries. LH severely impairs normal adaptation of pulmonary circulation in the perinatal period.

Acknowledgments We thank Valerie Zahra, Sally Gregg, Mary Hanna, Megan Probyn, and Samantha Louey for assistance in the experiments; Alex Satragno for assistance in fetal surgery; and Foula Sozo and Alison Thiel for assistance in biochemical assays.

\section{REFERENCES}

1. Moessinger AC, Santiago A, Paneth NS, Rey HR, Blanc WA, Driscoll JM Jr 1989 Time-trends in necropsy prevalence and birth prevalence of lung hypoplasia. Pediatr Perinat Epidemiol 3:421-431

2. Knox WF, Barson AJ 1986 Pulmonary hypoplasia in a regional perinatal unit. Early Hum Dev 14:33-42

3. Kilbride HW, Thibeault DW 2001 Neonatal complications of preterm premature rupture of membranes. Pathophysiology and management. Clin Perinatol 28:761-785

4. Kilbride HW, Yeast J, Thibeault DW 1996 Defining limits of survival: lethal pulmonary hypoplasia after midtrimester premature rupture of membranes. Am J Obstet Gynecol 175:675-681

5. Smith NP, Jesudason EC, Losty PD 2002 Congenital diaphragmatic hernia. Paediatr Respir Rev 3:339-348

6. Sherer DM, Davis JM, Woods JR Jr 1990 Pulmonary hypoplasia: a review. Obstet Gynecol Surv 45:792-803

7. Swischuk LE, Richardson CJ, Nichols MM, Ingman MJ 1979 Bilateral pulmonary hypoplasia in the neonate. AJR Am J Roentgenol 133:1057-1063

8. Potter EL 1946 Bilateral renal agenesis. J Pediatr 29:68-76

9. Perlman M, Williams J, Hirsch M 1976 Neonatal pulmonary hypoplasia after prolonged leakage of amniotic fluid. Arch Dis Child 51:349-353

10. Thibeault DW, Beatty EC Jr, Hall RT, Bowen SK, O'Neill DH 1985 Neonatal pulmonary hypoplasia with premature rupture of fetal membranes and oligohydramnios. J Paediatr 107:273-277

11. Dornan JC, Ritchie JW, Meban C 1984 Fetal breathing movements and lung maturation in the congenitally abnormal human fetus. J Dev Physiol 6:367-375

12. Yoshimura S, Masuzaki H, Miura K, Hayashi H, Gotoh H, Ishimaru T 1997 The effects of oligohydramnios and cervical cord transection on lung growth in experimental pulmonary hypoplasia in rabbits. Am J Obstet Gynecol 177:72-77

13. Collins MH, Moessinger AC, Kleinerman J, James LS, Blanc WA 1986 Morphometry of hypoplastic fetal guinea pig lungs following amniotic fluid leak. Pediatr Res 20:955-960

14. Pringle KC, Turner JW, Schofield JC, Soper RT 1984 Creation and repair of diaphragmatic hernia in the fetal lamb: lung development and morphology. J Pediatr Surg 19:131-140

15. Bohn D, Tamura M, Perrin D, Barker G, Rabinovitch M 1987 Ventilatory predictors of pulmonary hypoplasia in congenital diaphragmatic hernia, confirmed by morphologic assessment. J Paediatr 111:423-431

16. Kitagawa M, Hislop A, Boyden EA, Reid L 1971 Lung hypoplasia in congenital diaphragmatic hernia. A quantitative study of airway, artery and alveolar development. Br J Surg 58:342-346 
17. Barth PJ, Ruschoff J 1992 Morphometric study on pulmonary arterial thickness in pulmonary hypoplasia. Pediatr Pathol 12:653-663

18. Thibeault DW, Kilbride HK 1997 Increased acinar arterial wall muscle in preterm infants with PROM and pulmonary hypoplasia. Am J Perinatol 14:457-460

19. Levin DL 1978 Morphologic analysis of the pulmonary vascular bed in congenital left-sided diaphragmatic hernia. J Pediatr 92:805-809

20. Ting A, Glick PL, Wilcox DT, Holm BA, Gil J, DiMaio M 1998 Alveolar vascularization of the lung in the lamb model of congenital diaphragmatic hernia. Am J Respir Crit Care Med 157:31-34

21. DiFiore JW, Fauza DO, Slavin R, Wilson JM 1995 Experimental fetal trachea ligation and congenital diaphragmatic hernia: a pulmonary vascular morphometric analysis. J Pediatr Surg 30:917-924

22. Michel RP, Cruz-Orive LM 1988 Application of the Cavalieri principle and vertical sections method to lung: estimation of volume and pleural surface area. J Microsc 150:117-136

23. Joyce BJ, Louey S, Davey MG, Cock ML, Hooper SB, Harding R 2001 Compromised respiratory function in postnatal lambs after placental insufficiency and intrauterine growth restriction. Pediatr Res 50:641-649

24. Notter RH, Egan EA, Kwong MS, Holm BA, Shapiro DL 1985 Lung surfactant replacement in premature lambs with extracted lipids from bovine lung lavage: effects of dose, dispersion technique, and gestational age. Pediatr Res 19:569-577

25. Levin DL, Rudolph AM, Heymann MA, Phibbs RH 1976 Morphological development of the pulmonary vascular bed in fetal lambs. Circulation 53:144-151

26. Alcorn D, Adamson TM, Maloney JE, Robinson PM 1980 Morphological effects of chronic bilateral phrenectomy or vagotomy in the fetal lamb lung. J Anat 130:683695

27. Fewell JE, Hislop AA, Kitterman JA, Johnson P 1983 Effect of tracheostomy on lung development in fetal lambs. J Appl Physiol 55:1103-1108

28. Moessinger AC, Singh M, Donnelly DF, Haddad GG, Collins MH, James LS 1987 The effect of prolonged oligohydramnios on fetal lung development, maturation and ventilatory patterns in the newborn guinea pig. J Dev Physiol 9:419-427

29. Liggins GC, Vilos GA, Campos GA, Kitterman JA, Lee CH 1981 The effect of spinal cord transection on lung development in fetal sheep. J Dev Physiol 3:267-274

30. Adzick NS, Harrison MR, Glick PL, Villa RL, Finkbeiner W 1984 Experimental pulmonary hypoplasia and oligohydramnios: relative contributions of lung fluid and fetal breathing movements. J Pediatr Surg 19:658-665
31. Harding R, Hooper SB, Dickson KA 1990 A mechanism leading to reduced lung expansion and lung hypoplasia in fetal sheep during oligohydramnios. Am J Obstet Gynecol 163:1904-1913

32. Albuquerque CA, Smith KR, Saywers TE, Johnson C, Cock ML, Harding R 2002 Relation between oligohydramnios and spinal flexion in the human fetus. Early Hum Dev 68:119-126

33. Harding R, Hooper SB 1996 Regulation of lung expansion and lung growth before birth. J Appl Physiol 81:209-224

34. Wigglesworth JS, Desai R 1981 Use of DNA estimation for growth assessment in normal and hypoplastic fetal lungs. Arch Dis Child 56:601-605

35. Nakamura Y, Yamamoto I, Funatsu Y, Motomura K, Fukuda S, Hashimoto T, Morimatsu M 1988 Decreased surfactant level in the lung with oligohydramnios: a morphometric and biochemical study. J Pediatr 112:471-474

36. Hill AC, Adzick NS, Stevens MB, Mori H, Husseini W, Heymann MA 1994 Fetal lamb pulmonary hypoplasia: pulmonary vascular and myocardial abnormalities. Ann Thorac Surg 57:946-951

37. Rudolph AM, Yuan S 1966 Response of the pulmonary vasculature to hypoxia and $\mathrm{H}^{+}$ion concentration changes. J Clin Invest 45:399-411

38. Tiktinsky MH, Morin FC 3rd 1993 Increasing oxygen tension dilates fetal pulmonary circulation via endothelium-derived relaxing factor. Am J Physiol 265:H376-H378

39. Fuhrman BP, Smith-Wright DL, Venkataraman S, Orr RA, Howland DF 1989 Proximal mean airway pressure: a good estimator of mean alveolar pressure during continuous positive-pressure breathing. Crit Care Med 17:666-670

40. Walker AM, Ritchie BC, Adamson TM, Maloney JE 1988 Effect of changing lung liquid volume on the pulmonary circulation of fetal lambs. J Appl Physiol 64:61-67

41. Fuhrman BP, Everitt J, Lock JE 1984 Cardiopulmonary effects of unilateral airway pressure changes in intact infant lambs. J Appl Physiol 56:1439-1448

42. Peliowski A, Finer NN, Etches PC, Tierney AJ, Ryan CA 1995 Inhaled nitric oxide for premature infants after prolonged rupture of the membranes. J Pediatr 126:450 453

43. Geary C, Whitsett J 2002 Inhaled nitric oxide for oligohydramnios-induced pulmonary hypoplasia: a report of two cases and review of the literature. J Perinato 22:82-85

44. Karamanoukian HL, Glick PL, Zayek M, Steinhorn RH, Zwass MS, Fineman JR, Morin FC 3rd 1994 Inhaled nitric oxide in congenital hypoplasia of the lung due to diaphragmatic hernia or oligohydramnios. Pediatrics 94:715-718 